\title{
Socialization, learning and perception of urban landscape: the case of Estella-Lizarra
}

\author{
U. Domblás \\ Heritage, Planning and Landscape, Department of Geography, \\ Prehistory and Archaeology, Faculty of Letters, \\ University of the Basque Country (UPV/EHU), Spain
}

\begin{abstract}
Citizenship is changing, as is urban management, therefore so is the way we perceive landscape. New technologies are helping us to obtain more participation ability and boost a shared transformation of the territories we inhabit.

Tactical urbanism and open source urban planning, in which everyone might feel a part by participating and contributing knowledge, is in a day's order. This shared knowledge, focused on urban landscape can help to promote the appreciation of unseen and unknown spaces around us.

This paper shows how to approach the heritage to the citizenship in both an amusing and educational way at the same time.

After a brief discussion in which we will review the cases where the introduction of new technologies (ICT) benefits the learning, perception and evaluation of the urban landscape that surround us, we will explain in detail how some experiences placed in the Camino de Santiago, passing from Estella (Navarra), should be provided. This environment has many factors which give a deep territorial identity. Its intense medieval roots, strategic location and landscape diversity (tangible and intangible), remarks this identity and makes it unique.

These experiences will be the result of the collaboration between different cultural agents working in the area as well as the citizens themselves. It is intended, likewise, to involve the tourist or pilgrim who perceives that landscape for the first time and to find, this way, a glocal point of view (global + local) that will contribute to a better enhancement of this heritage from that crossed knowledge. Keywords: urban landscape, socialization, heritage.
\end{abstract}




\section{Introduction}

The city is a complex organism in constant evolution - multiple information layers that mutate over time, but hiding the footsteps of the past.

These footsteps are its history, shapes its identity and distinguishes it from the rest making it unique.

However, we are not always aware of what surrounds us even less, wondering the origin of some elements that conform the urban landscape.

The concept of landscape has existed since its origin, directly attached with the sense of sight putting into background any other possible kind of perception.

If we pay attention to the encyclopaedic acceptation of the word, we find phrases such as "expanse of a plot that its seen from a place", "expanse of a plot considered in its artistic aspect" or "painting, sketch that represents certain expanse of a plot" RAE (Spanish Royal Academy).

The interpretation and significance collected until now are quite diverse although its necessary influence in the idea that the landscape it is not an objectual entity, but also a group of sensations and comprehension we perceive as soon as we observe a place.

Therefore, in urban landscape term, we would not make references to the city itself, but the concept that it is deducted from it, in the case we take note of all the impressions.

Paintings, sketches, engravings or the photographs have been the clue in the evolution of the viewing and understanding of the urban landscape and little by little using those techniques, sensations and atmospheres have been transmitted but not always answering to a visual aspect.

These disciplines, even being objective, have tended - and tend - to be general and united answering to different fashion or aesthetic mainstreams.

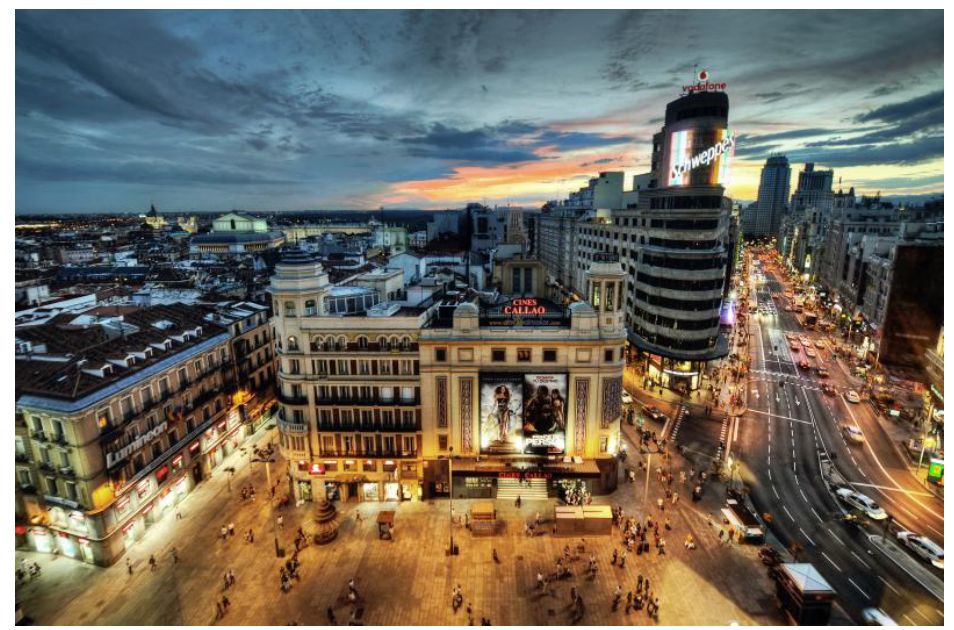

Figure 1: José María Cuellar; Gran Vía St., Collao Sq. Madrid, 2nd June 2010 [1]. 
Today we ask more to a place, we ask for authenticity, security, feelings and a new experience. We enjoy the cities beyond the sight, we remember music, smells, textures and flavors. A world of sensations that we match with food, bars, dance, shops, etc., that provide personality to the place. We take cards as souvenirs, but also fabrics, or bottled sea-sand.

If that were not enough, we contribute to the digital identity and to the socialization of the city, we take pictures, uploading them to the web, we share corners, urban transport tricks or geo-located pictures apps, even informative sheets that are unfold in front of us like in an augmented reality (Ruiz Torres [2]).

\section{Socialization of the urban landscape}

It is noticed a lack of learning, perception, and value in the urban landscape that surrounds us.

The citizens are changing, urban management is changing as well, and this makes that the way we perceive it landscape modifies too. New technologies are helping us to have wider participation ability and benefit the place we inhabit.

New manners of understanding the city emerge, or like Di Siena calls it, city of knowledge: "A sensitive city to the movements, actions and thinking of their own citizens, a city which is capable of feeding the culture and the local identity, improving the connections among the citizens, taking advantages of the gestures, activities and the most quotidian interests." (Di Siena [3]).

Strategic planning and the open source urbanism, in which all the world could feel part contributing knowledge in an active way, it is trendy.

This shared knowledge devoted to the urban landscape atmosphere could help to apprehend and benefit the value of invisible and unknown places of our environment.

\subsection{TIC as a clue tool of the process}

It is necessary to establish relationships among the different cultural agents and to promote spaces where the citizens could express and remember in loud voice those linked places not only to the tangible heritage, but also to the intangible, which is the one that completes the identity of a site.

Pictures, drawings, engravings or books with their urban tales help to preserve the landscape through the centuries, even though it is alive and in constant evolution.

Until now there were a few selected people to make such an important contribution like photographs, or well-known artist, besides the institutions or city halls. Associations or groups, for their part, have been clear transmitter of knowledge and responsible of our perception towards a place. Speech organizations, workshops and courses set the interrelationship among the relative aspects to the cultural layer, tend to be more often the simplest way that completes the grupal imaginary of a city. 
However, nowadays in this opened and more collaborative moment than ever, when we get it clear that if we give $1 \%$ of our knowledge, we will receive the same percentage of 10 more people and therefore it is when we need to participate individually, as a local agent who has its own vision to contribute although we do not take part of any cultural group.

Tic provides that unique scale in which can co-exist on one side the most wellknown history researcher and on the other any kind of citizen.

The use of this kind of tools in the city is more natural. Several cities are being added to the Smarts cities and participate even, in congress and meetings in which they look for ideas to implement management improving and develop its branding.

The next evolutionary step, is to aim that the citizen participates not only in a critic way but also in a proposed one, the Smart Citizens.

In this way the citizens could contribute the function planning of their environment in a usual manner through web sites, or apps, etc.

Words like empowerment or participation are implicit in our speech without mentioning and new collaborative projects appear everyday con the intention of getting, in certain way, social support.

The educational and civic ambit spring up projects such as Malaga propone (García Ramos [4]) and Repara ciudad (ODC [5]) the first it is one of the first online citizens platforms in which the neighbors could propose uses of places with opportunity in the city of Malaga, the second one it is a platform that is still in used - and that let report incidents with the urban equipment, pavement of Barcelona City.

There are other projects like maTIKomapa (Zaramari [6]), mapping workshop and urban narrative, in which the proposal and report melt, being their own neighbors the ones that decide which routes are able to be researched meanwhile they propose solutions to the needs highlighting the neighborhood proud thank to the digital tools.
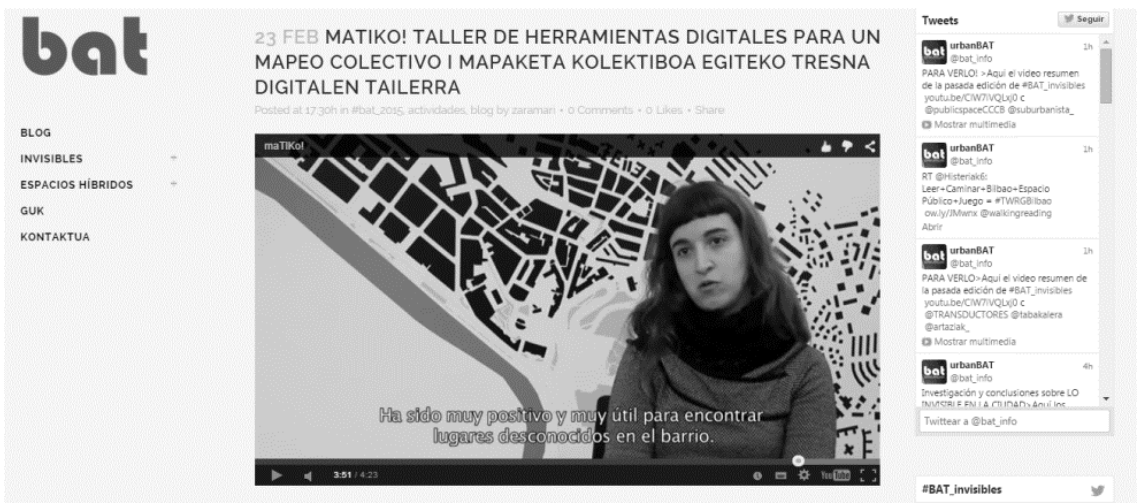

Figure 2: Zaramari, maTIKomemoria project, Uríbarri, Bilbao (Bizkaia), February 2015 [7]. 


\section{Samples of urban landscape socialization: passive socialization and active socialization}

There are multiple tools and processes that are being developed through the implementation of the new technologies (TIC), helping to the development of socialization methodologies adding global conclusions and contributing to the enhancement of the heritage from the citizen's knowledge and learning.

Between the types of socialization we may distinguish the passive one, in which the citizens are receptors of previously shaped information, and the active, in which the citizens perform or produce it.

\subsection{Sample of passive socialization in the city:}

Increased reality application for guided tours in Salamanca by the University Club of Innovation.

"The increased reality applications in the smart phones or tablets add useful information to the scenery in which the consumer moves.

Publicity students have develop the first application of increased reality for mobile phones devoted to the tourism of Salamanca city, bound for the Scala Coeli visit that allow getting to the towers of Clecería, headquarters of the Universidad Pontificia of Salamanca.

The application offers extra information about the city form an exceptional place to stare at." (DiCYT [8]).

\subsection{Sample of active socialization in the city:}

\section{Project Kopf - Urban intervention in Istanbul by On/Off Network.}

"During more than two months we made a series of experimental trips in our city by night. Our idea was to activate latent potentialities of our urban environment, white facades, overcrowded streets, and the characters that belong to what we understand as a city.

We have generated a tool, an amplification object that could be negotiated and taken over by the citizens.

The object amplifies alive actions from the environment with a camera and the curiosity of pedestrians made them get closer and start interacting spontaneously with the object.

Suddenly, everybody become actors of its natural habitat. With that discovery they have the power of changing and producing the urban space" (On/Off [9]).

\section{The case of Estella-Lizarra}

\subsection{Context}

The city of Estella-Lizarra has been, from the beginning conditionally shaped to its natural limits. Hills and little mountains on one side, the Puy, San Lorenzo, Monte Alto, Cruz de los Castillos, Oncineda, Atieta, Santa Bárbara and Ibarra. 
The little mountains make the defense strategic line of the city, on the background Belástegui, San Millán, Montejurra y Monjardín. As a third determinant factor in the evolution of the city: the river Ega.

The first settlers set up in defensive sites like the hillside of the Puy and de la Cruz de los Castillos, the unavoidable urban expansion makes that little by little this growth start heading to the shore of the river. Through the centuries, the river has set the natural boundary between the neighborhood of San Pedro de la Rúa o San Martín and the forthcoming San Miguel and San Juan.

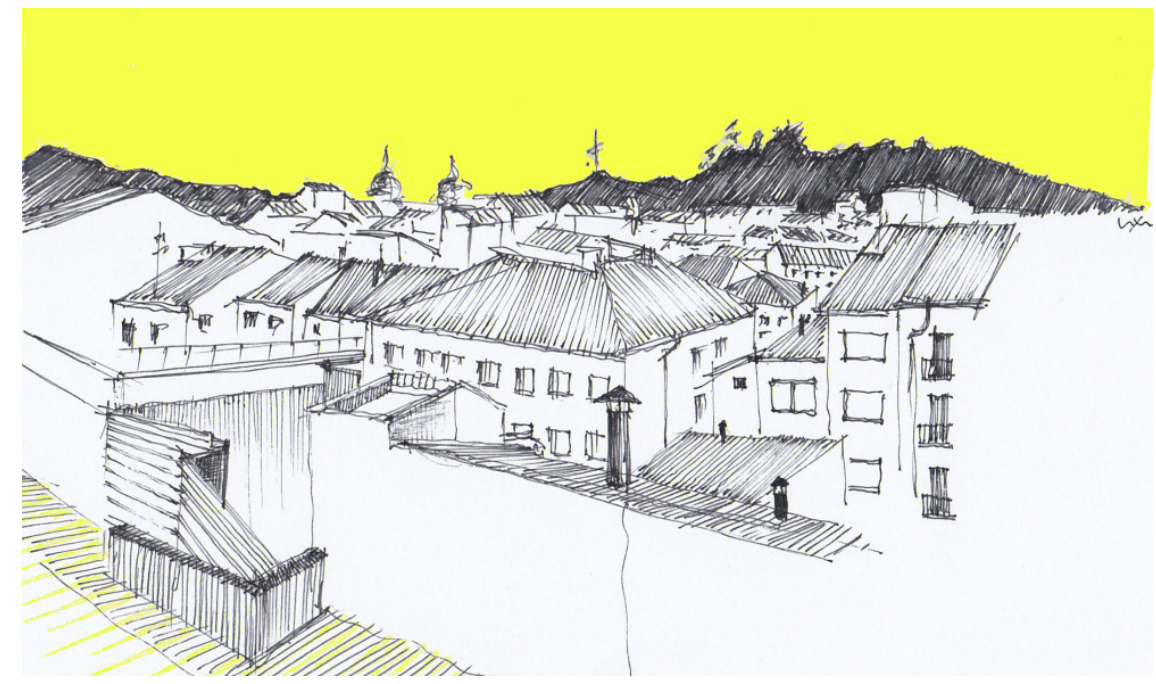

Figure 3: Uxua Domblás; Roofts, Estella-Lizarra (Navarra), January 2015.

There are several testimonies about the activity of the human being in this territory. Since tools and ceramic rests that bring us to the Lower - middle Paleolithic, until the Roman paths, Visigoths or Muslim terms passing by the Iron Age site.

Estella keeps being in the city-market role and in its dairy life could be overappreciated this condition that has since it belonged to the Santiago Path in the century XI. The market square, shops, and the celebration of the trader association remind us how the rural life and the manufacture have been undeniable at the moment of supplying all the need of the native people and also of pilgrim and visitors.

Besides castles, walls, churches and convents la city preserves a huge inheritance of that glorious era that will affect even to the toponymy of the place like the gremial industry.

\subsection{Tannery industry}

One of the industries with more support and that punctually survives in the city is the tannery industry. 
Since the middle ages, stalls and fur shops, were placed nearby the Ega, getting profit of the force of it stream to clean leathers. In this way, this kind of workshops were colonizing both shores of the river and making up the back facades that no one look at. In the basement level, in direct contact with the water and with lots of wells, the tannery and cleaning area, in the intermediate area the living space or office, and below the roof the dry-level area. Those constructions alter with the usual typologies in medieval cities (narrow plot with gremial workshop on ground zero and living space above) and configure the one that during centuries would be the entrance to the city.

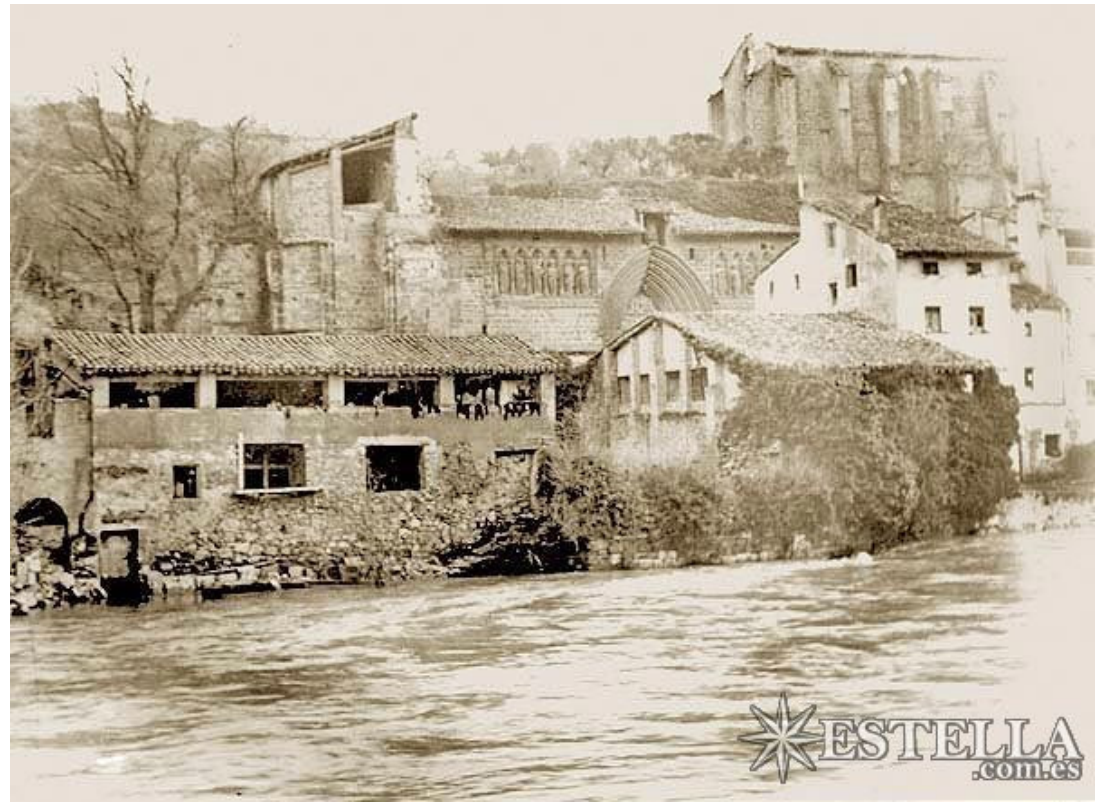

Figure 4: Julio Ruiz de Alda's great-grandfather's tannery [10].

However, the front part of the street, that belongs to the Jacobean route, that has suffered meaningful alterations through the centuries. Big palaces and houses with special aesthetic protection in the facades, pavement changes and other elements but, moreover, it has been broadcasted and socialized its most proud history with interest, leaving behind that industrial memory which could be still read in its back parts.

This inheritance, keeps alive in local gremial groups like shoe-makers, printers, fur-shoppers, or leather worker, but the recent discovery of an antique tannery in a digging shows this intangible heritage, the medieval tannery industry as the epicenter of a workshop net and derivative services.

Hence, taking part in the $\mathrm{PhD}$ process in which not only a methodology for the heritage patrimony it is trying to be exposed, but also it will study the case of the tannery industry of Estella-Lizarra as a pilot experience. Learning City Project is the methodological framework in which this concept is explored. 


\section{Learning city project: the tanning industry as an object of study}

\subsection{Project}

The process of an opened $P h D$.

It is introduced as an involving project of the researching about the Urban Landscape of the Santiago path through Estella-Lizarra (Navarra).

This environment has several factors that bring it of a deep territorial intensity. Its intense middle-aged support, its strategic settlement and the landscape diversity (tangible and intangible) highlight it identity making it unique.

Based on a pilot experience linked with the industrial and trade layer, which has been decisive into the city configuration, toponymy, traditions and others.

The main goal is to socialize and bring closer part of this heritage to the citizenship in a didactic and playful way.

\subsection{Methodology}

An investigation process is based basically on, in the interference found in the experience. In this case, they will be several and from very diverse types.

Although for the development of those experiences we have to build up a parallel data collecting methodology, testimonies, idea-sharing and a way to spread out all the discovered material. It is based on designing adequate activities to each social group, with the intention of representing the majority of the population.

The project is divided in 3 important areas that work simultaneously: Investigation, Experiences and Broadcasting.

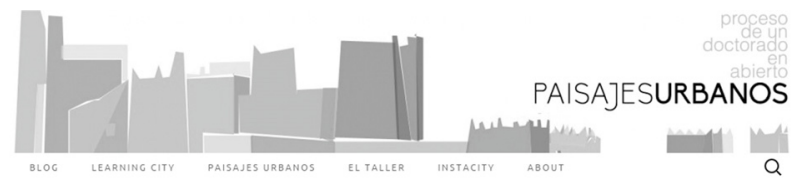

BERLIN: SYMPHONY OF A GREAT CITY.
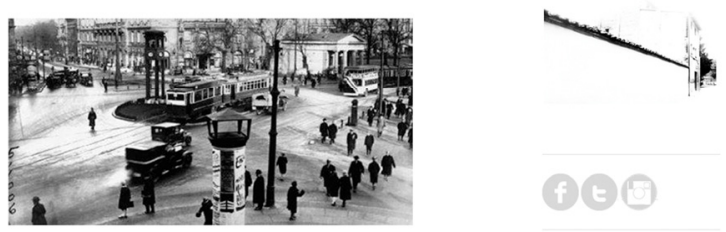

ÚLTIMAS ENTRADAS

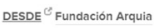

Berlin: Symphony of a Great City.

iDocumental con muy ouena pinta:

La ciudad tridimensional: Como mpactarán los drones el paisaje

Año 1927, expresionismo alemón... y imudo! Esperemos que tenga buena BSO

Sentient Identity o como usar la

as comuniclades pere proximider

Figure 5: Uxua Domblás, Learning City Project, Estella-Lizarra, 2014 [11]. 


\subsection{Three areas of the project}

\subsubsection{Investigation}

The importance of melting the theory and practice.

This investigation wants to develop a socialized methodology in a specific place, but at same time, that could be extrapolated to other territory.

So that, it is understandable the fusion between the theory and the practice, to promote the mix between the exactitude and the scientific method with the spontaneity and the conclusions taken from the experiences.

\subsubsection{Experiences: the human laboratory}

The importance of the physical place for the development of the experiences.

As a base camp, initial point or exposition of any of the experiences it will be used of a street workshop as a laboratory.

Once we have collected the information, this could be organized and exposed in one of the culture classrooms that the Estella-Lizarra City Hall has.

Experiences:

In the empiric character of sociological studies in which data collecting it's expected to give conclusions to precise social phenomenons is a usual practice the realization of surveys or questionnaires.

These surveys could appear in different formats but also could be translated to more current collaborative tasks that may adapt better to each one of the groups.

Tonucci says that "The most important learning in life is made playing" (Tonucci [12]). He refers to the first stage of a human being, from 0-6 years old, however, we must not leave behind the idea of approaching the heritage to the citizen, no matter which age, in a ludic way may be more effective or at least more complementary, to the traditional way.

For that a series of precise experiences have been designed and focused to the territory of Estella in which, besides the memory, all the senses will try to be incorporated through games and technological tools of socialization.

Regarding to the types of socialization already mentioned in the point 3, we will divide the experiences in 2 types:

a) Passive experiences

- Mapping over the wall in the river area

- Treasure search and routes with RA

- Visits to the old tannery

b) Passive experiences:

- Urban drift

- Micro interviews

- Urban landscape workshops

\subsubsection{Broadcasting: blog and social media}

The importance of the human being on the web, local and worldwide sharing.

The process of investigation, the developed experiences, and their conclusions will be disseminated with the intention of sharing all that we have learnt. Moreover, sharing this information will help us to sew a contact net with physical people 
devoted to the topic and with whom we will meet up in different socialization experiences that are being used in other cities.

5.3.3.1 The workshop The place in which it will be held the majority of the opened research, where the parts of the investigation process will be exposed in a way that the neighbors may be informed about it, otherwise giving first hand information.

5.3.3.2 Blog/RS The translation of the online process. The main goal is to promote the exchange of methodologies, tools and knowledge using the web. As it has been mentioned before, both interactions, local and global are important, much more in such an overcrowded place like Estella-Lizarra for being in a clue site of the Santiago path.

5.3.3.3 Traditional media Besides, the diffusion through the traditional media: radio, newspapers, boards.

\section{Conclusions}

"When a transparent urban landscape does not say anything to the observer, it is not because of its messy nature, trivial or mayfly, it is because of the sensorial observer limitations." (Pellitero [13]).

The heritage socialization, tangible or intangible, involves something else than get to know what already exists. It means visualizing elements, promoting a sensitive city, getting involved the citizen into the process, teaching him or her, embracing the information, adding his or her testimony, so it could be melted with the place memory to belong to its identity.

\section{References}

[1] Image taken from the Flickr website: http://kcy.me/1r2es

[2] Ruiz Torres D., Augmented reality and Cultural Heritage: new perspectives for the knowledge and dissemination of the cultural object, e-rph: Revista Electrónica de Patrimonio Histórico (online) 2011. http://www.revistadepatrimonio.es/revistas/numero8/difusion/estudios2/art iculo

[3] Di Siena, D. Sentient City: City of knowledge, dpr-barcelona, 2012, www.dpr-barcelona.com

[4] García Ramos, A., Málaga propone. De la ciudad 1.0 a la ciudad 2.0, Recolectores Urbanos ed. Sevilla, 2012.

[5] Opened Data Cities SL, ODC http://reparaciudad.com/

[6] Zaramari, maTIKo!, Auzo Factory Irazabal Matiko, Bilbao, 2015 http://urbanbat.org/2015/02/23/matikomapa/

[7] Screenshot taken from the website of Ubiqarama: ubiqarama.org/route/matikomemoria/

[8] DiCYT, https://www.youtube.com/watch?v=9w3bBHbMdcU 
[9] On/Off Network studio, https://onoffnetwork.wordpress.com/ 001-kopfkino/

[10] Image taken from the website: http://estella.com.es/

[11] Screenshot taken from the website of Learning City Project: learningcityblog.com

[12] Tonucci, F. The city of children: a new way of thinking the city, Fund. German sanchez ruiperez, Madrid, 2004.

[13] Ana M Moya Pellitero The perception of Urban Landscape, at Biblioteca Nueva (ed.), Madrid, p. 57, 2011. 